\title{
EFFECTIVENESS OF MONEPANTEL AND LEVAMISOLE TO CONTROL GASTROINTESTINAL STRONGYLID PARASITES OF SHEEP
}

\author{
EFICÁCIA DE MONEPANTEL E LEVAMISOL NO CONTROLE DE \\ ESTRONGILÍDEOS PARASITOS GASTRINTESTINAIS DE OVINOS
}

\section{Andreia Zago CIUFFA'; Mylla Christhie Costa URZEDO²; Danilo Mundim SILVA'; Bruno Cabral PIRES'; ${ }^{1}$ Laís Miguel REZENDE'; Silvia Cassimiro BRASÃO; Gilberto de Lima MACEDO JÚNIOR ${ }^{3}$; Fernanda ROSALINSKI-MORAES ${ }^{3}$.}

1. Mestrando(a) do Programa de Pós-Graduação em Ciências Veterinárias, Universidade Federal de Uberlândia - UFU, Uberlândia, MG, Brasil; 2. Graduanda em Zootecnia, Universidade Federal de Uberlândia - UFU, Uberlândia, MG, Brasil; 3. Professor Doutor, Faculdade de Medicina Veterinária, Universidade Federal de Uberlândia - UFU, Uberlândia-MG, Brasil. fernanda.rosalinski@ufu.br

\begin{abstract}
Anthelmintic resistance poses a major challenge to the control of endoparasites in sheep. The recent launch of monepantel may represent an alternative for the treatment of helminth infections. The purpose of this study was to assess the effectiveness of monepantel and levamisole in the sheep flock on the experimental farm Capim Branco, of the Federal University of Uberlandia, municipality of Uberlandia, state of Minas Gerais, Brazil. Thirty sheep with more than 200 eggs per gram of feces (EPG) were selected. Ten of these animals were treated orally with $2.5 \mathrm{mg} / \mathrm{kg}$ of monepantel, ten were treated subcutaneously with $7.5 \mathrm{mg} / \mathrm{kg}$ of levamisole, and ten served as control animals. Fecal samples for the determination of EPG were collected on days zero (pre-treatment), seven and fourteen (post-treatment). The percentage of effectiveness was calculated using RESO 2:01 software. Monepantel reduced the EPG of Haemonchus sp. and Trichostrongylus sp. by more than 95\%, but Oesophagostomum sp. was reduced by only 50\% and 33\% on days seven and fourteen. The percentage reduction of EPG by levamisole remained above $95 \%$ for all the helminths recovered from fecal cultures, indicating its effectiveness. These data demonstrate the failure of monepantel to control Oesophagostomum spp. in the evaluated sheep flock.
\end{abstract}

KEYWORDS: Resistance. FECRT. Oesophagostomum sp.

\section{INTRODUCTION}

Sheep may present severe or chronic worm infection, the former leading to rapid death and the latter causing losses in weight gain, wool production, lower reproductive efficiency, and greater susceptibility to disease (SCZESNYMORAES et al., 2010). Anthelmintic resistance is widespread in Brazil, and is the main problem faced by the sheep industry. Resistance is the hereditary ability of a population of parasites to reduce their sensitivity to the action of drugs to which they have been previously exposed (FIEL et al., 2003).

The excessive use of anthelmintics, incorrect administration of dosages lower than those internationally recommended and misdiagnoses of worm infections that lead to the unnecessary use of drugs has caused gastrointestinal parasites to become drug-resistant (SOUZA et al., 2008). Veríssimo et al. (2012) made a survey of the current situation of parasite resistance in the state of São Paulo (southeast Brazil) and found that $53.6 \%$ of the 30 flocks they evaluated were resistant to the five anthelmintic groups they tested: albendazole, closantel, ivermectin, levamisole, and moxidectin.
In view of the failure of traditional broad spectrum drugs, the recent launch of the active ingredient monepantel, of the class of aminoacetonitrile derivatives (AADs), may offer an alternative for the treatment of helminth infections, associated with other integrated management tools (KAMINSKY et al., 2008a).

This study aimed to evaluate the effectiveness of monepantel and levamisole in a flock of sheep with a history of resistance to macrocyclic lactones and benzimidazole.

\section{MATERIAL AND METHODS}

The study was conducted at the Capim Branco Experimental Farm of the Federal University of Uberlândia (UFU), in the municipality of Uberlândia, state of Minas Gerais, Brazil. The sheep flock comprises Santa Inês and Dorper crossbreeds. No new animals were introduced into this flock in the last four years prior to this study. To control gastrointestinal worms, the animals are monitored by means of fecal examinations and the FAMACHA $^{\Theta}$ system. Whenever necessary, a selective treatment is administered with a subcutaneous dose of $7.5 \mathrm{mg} / \mathrm{kg}$ of levamisole. This 
flock was never treated with monepantel prior to this study, although there is a record of loss of efficacy of macrocyclic lactones and benzimidazoles. The effectiveness of levamisole and monepantel in this flock was monitored using the protocol described by Coles et al. (2006), which compares the average reduction of EPG counts in groups of treated animals against an untreated control group, seven and fourteen days after administration of the active ingredients to be tested. To this end, 30 sheep were selected which presented a count of more than 150 EPG. A modified version of the Gordon and Whitlock (1939) method was used, which is sensitive to 50 EPG.

On day zero of the experiment, feces were collected, the animals were weighed, and the first two groups of sheep were randomly placed into one of three groups of 10 animals each: Monepantel (2.5 $\mathrm{mg} / \mathrm{kg}$, administered orally); levamisole $(7.5 \mathrm{mg} / \mathrm{kg}$, administered subcutaneously), and an untreated control group. The feces were sent to the Laboratory of Parasitic Diseases at UFU for determination of the EPG values by the Gordon and Whitlock (1939) method, and fecal culture was performed by the Roberts and O'Sullivan (1950) method. The
CIUFFA, A. Z et al

morphological key proposed by Van Wyk et al. (2004) was used to identify the larvae recovered from the fecal cultures. The procedures for feces collection, EPG counts and fecal cultures for the three groups were repeated 7 and 14 days after administration of the anthelmintics.

The efficacy rate of the anthelmintics was calculated using RESO 2:01 software, based on the difference between the average post-treatment EPG count (day 7 and 14) of each group separately, and the average EPG count of the control group, also on day 7 and 14. For the anthelmintic to be considered efficient, the treated group should present a 95\% reduction of EPG in relation to the control group, and the average 95\% confidence interval must be higher than 90\% (WURSTHORN; MARTIN,1990). The program considers the results of fecal cultures and displays the EPG percentage reduction by worm genus.

\section{RESULTS AND DISCUSSION}

The average EPG counts were reduced after the administration of both the anthelmintics (Table $1)$.

Table 1. Fecal egg counts (mean eggs per gram (epg), range (minimum-maximum)), results of fecal egg count reduction test (reduction percentage and 95\% CL), larval percentage and reduction percentage in coproculture of sheep from the untreated control group and the group treated with $7.5 \mathrm{mg} / \mathrm{kg} \mathrm{of}$ levamisole or $2.5 \mathrm{mg} / \mathrm{kg}$ of monepantel in Uberlândia, Minas Gerais, Brasil.

\begin{tabular}{|c|c|c|c|c|c|c|c|c|c|}
\hline \multirow[t]{3}{*}{ Group } & \multicolumn{3}{|c|}{ Control Group $(n=10)$} & \multicolumn{3}{|c|}{ Levamisol $(n=10)$} & \multicolumn{3}{|c|}{ Monepantel $(n=10)$} \\
\hline & \multirow{2}{*}{$\begin{array}{l}\text { pre-treatment } \\
(\mathrm{d} 0)\end{array}$} & \multicolumn{2}{|c|}{ post-treatment } & \multicolumn{3}{|c|}{ post-treatment } & \multirow{2}{*}{$\begin{array}{l}\text { pre-treatment } \\
(\mathrm{d} 0)\end{array}$} & \multicolumn{2}{|c|}{ post-treatment } \\
\hline & & $(d 7)$ & $(\mathrm{d} 14)$ & & $(d 7)$ & (d14) & & $(d 7)$ & $(\mathrm{d} 14)$ \\
\hline Mean (EPG) & 2518.7 & 3006.2 & 4766.6 & 2091.6 & 10.0 & 77.7 & 2000.0 & 31.2 & 57.1 \\
\hline Range (EPG) & $150-3850$ & $500-7400$ & $100-9900$ & $300-7750$ & $0-50$ & $0-300$ & $750-5100$ & $0-150$ & $0-200$ \\
\hline Reduction (\%) & & & & & 100 & 98 & & 99 & 99 \\
\hline Upper $95 \%$ CL & & & & & 100 & 99 & & 100 & 100 \\
\hline Lower $95 \% \mathrm{CL}$ & & & & & 99 & 95 & & 96 & 96 \\
\hline $\begin{array}{l}\text { Haemonchus sp. } \\
\text { (\% recovery) }\end{array}$ & 90 & 86 & 82 & 85 & 60 & 55 & 78 & 0 & 0 \\
\hline $\begin{array}{c}\text { Trichostrongylus sp. } \\
\text { (\% recovery) }\end{array}$ & 8 & 12 & 15 & 13 & 37 & 43 & 19 & 0 & 0 \\
\hline $\begin{array}{l}\text { Oesophagostomum } \\
\text { sp. (\% recovery) }\end{array}$ & 2 & 2 & 3 & 2 & 3 & 2 & 3 & 100 & 100 \\
\hline $\begin{array}{c}\text { Haemonchus sp. } \\
\text { (Reduction \%) }\end{array}$ & & & & & 100 & 99 & & 100 & 100 \\
\hline $\begin{array}{l}\text { Trichostrongylus sp. } \\
\quad \text { (Reduction \%) }\end{array}$ & & & & & 99 & 95 & & 100 & 100 \\
\hline $\begin{array}{l}\text { Oesophagostomum } \\
\text { sp. (Reduction \%) }\end{array}$ & & & & & 99 & 97 & & 50 & 33 \\
\hline
\end{tabular}


The percentage reduction of EPG obtained with levamisole on days 7 and 14 was higher than 95\% and fell within the predicted confidence interval. Upon converting the EPG values by the percentage of genera obtained from the fecal cultures, a reduction of more than $95 \%$ was also found for Haemonchus sp., Trichostrongylus sp. and Oesophagostomum sp. Thus, all the genera were considered susceptible to the active ingredient of levamisole (Table 1).

The percentage reduction of EPG obtained with monepantel on days 7 and 14 was higher than 95\%, except for Oesophagostomum spp., reaching values of $50 \%$ and $33 \%$ on days 7 and 14 , respectively, which indicates low or initial resistance of the genus to the active ingredient (Table 1).

The results demonstrated that levamisole is still effective, even though this active ingredient has been used on the Capim Branco experimental farm for at least two consecutive years. It is possible that, as suggested by Torres-Acosta et al. (2012) and Park et al. (2015), the targeted selective treatment based on FAMACHA ${ }^{\odot}$ and fecal egg counts are being able to preserve Refugia population and thus, of maintaining drug effectiveness throughout this period.

The efficacy of levamisole is consistent with those described by Sprenger et al. (2013), who reported the effectiveness of this active ingredient in doses of 9.00 and $6.75 \mathrm{mg} / \mathrm{kg}$ administered to sheep on a farm in the municipality of Balsa Nova, state of Paraná, Brazil. On the other hand, several authors have reported the ineffectiveness of this drug in flocks of sheep in Brazil. Among 17 farms in the region of Jaguaribe, state of Ceará, $41 \%$ were resistant to levamisole (MELO et al., 2003). This active ingredient was also reportedly ineffective in $44 \%$ of 9 farms in the state of Santa Catarina (ROSALINSKI-MORAES et al., 2007) and 86.7\% of 16 farms in the state of Mato Grosso do Sul (SCZESNY-MORAES et al., 2010).

The results of monepantel indicated the effectiveness of the active ingredient on Haemonchus sp. and Trichostrongylus sp., the genera most frequently involved in anthelmintic resistance reported in Brazil (VERÍSSIMO et al., 2012)

After 25 years without the launch of any new anthelmintic drug, monepantel emerged as an alternative for worm control because of its high efficacy against several multidrug resistant nematodes and because it is well tolerated by sheep (KAMINSKY et. al., 2008b). However, although it is a new molecule without a history of use in the animals of the Capim Branco experimental farm, monepantel did not prove effective against Oesophagostomum sp.

This result is in agreement with that reported by Kaminsky et al. (2009), who obtained 99.8 to $100 \%$ of effectiveness in the elimination of Haemonchus sp. and Trichostrongylus sp. with a dose of $1.25 \mathrm{mg} / \mathrm{kg}$. However, when these authors administered a dose of $2.5 \mathrm{mg} / \mathrm{kg}$, the same as that used in this experiment, all the tested helminths were susceptible except Oesophagostomum venulosum and Chabertia ovina, which might indicate a reduced susceptibility or development of tachyphylaxis by Oesophagostomum sp. to aminoacetonitrile derivatives when compared to other strongylid nematodes. Hoskins et al. (2010) attested that the efficacy of the dosage of $2.5 \mathrm{mg} / \mathrm{kg}$ monepantel was $92.7 \%$ for a pool of different isolates of adult stages of $O$. venulosum, and that this could be the dose-limiting nematode and stage for the drug.

Besides the recent launch of monepantel into international market, resistance of Teladorsagia circumcinta (SCOTT et al. 2013), Trichostrongylus colubriformis (SCOTT et al. 2013; CINTRA et al., 2016) and Haemonchus contortus (MEDEROS et al., 2014; VAN DER BROM et al. 2015) have been reported. Thus, we suggest that the effectiveness of monepantel in flocks should be monitored based on a combination of EPG counts and fecal cultures, and if necessary, substitute or associate it with other broad spectrum drugs. This might be even more important in geographic regions where Oesophagostomum spp. are prevalent.

\section{CONCLUSIONS}

Levamisole was effective in controlling Haemonchus sp., Trichostrongylus sp. and Oesophagostomum sp. in the flock of sheep under study in the region of Uberlândia, Minas Gerais.

Monepantel was effective against the same gastrointestinal parasites, except for Oesophagostomum spp..

RESUMO: A resistência anti-helmíntica é um dos maiores desafios para o controle de endoparasitos em ovinos. O recente lançamento do monepantel pode representar uma alternativa para o tratamento das helmintoses. Este trabalho objetivou avaliar a eficácia do monepantel e levamisol no rebanho ovino da Fazenda Capim Branco da Universidade 
Federal de Uberlândia, em Uberlândia, Minas Gerais. Foram selecionados trinta ovinos com valores de ovos por grama de fezes (OPG) superiores a 200. Destes animais, dez foram tratados com monepantel 2,5 mg/kg, via oral, dez receberam tratamento subcutâneo com levamisol 7,5 mg/kg, e os outros 10 permaneceram como animais controle. No dia zero (prétratamento), sete e quatorze (pós-tratamento), realizou-se coletas de fezes para determinação de OPG. O percentual de eficácia foi calculado pelo software RESO 2.01. O monepantel apresentou percentual de redução superior a $95 \%$ para Haemonchus sp. e Trichostrongylus sp., porém este percentual para Oesophagostomum sp. foi de 50\% e 33\%, no sétimo e décimo quarto dia. O percentual de redução de OPG para levamisol se manteve superior a 95\% para todos os helmintos recuperados nas coproculturas, indicando sua eficácia. Estes dados indicam a falência do monepantel em realizar o controle de Oesophagostomum spp. no rebanho avaliado.

PALAVRAS-CHAVE: Resistência. Teste de redução de OPG. Oesophagostomum sp.

\section{REFERENCES}

CINTRA, M. C. R.; TEIXEIRA, V. N.; NASCIMENTO, L. V.; SOTOMAIOR, C. S. Lack of efficacy of monepantel against Trichostrongylus colubriformis in sheep in Brazil. Veterinary Parasitology, Genebra, v. 216, p. 4-6, jan. 2016. https://doi.org/10.1016/j.vetpar.2015.11.013

COLES, G. C.; JACKSON, F.; POMROY, W. E.; PRICHARD, R. K.; SAMSON-HIMMELSTJERNA, G.; SILVESTRE, A.; TAYLOR, M. A.; VERCRUYSSE, J. The detection of anthelmintic resistance in nematodes of veterinary importance. Veterinary Parasitology, Genebra, v. 136, p. 167-185, mar. 2006.

https://doi.org/10.1016/j.vetpar.2005.11.019

FIEL, C.; ANZIANI, O.; SUÁREZ, V.; VÁZQUEZ, R.; EDDI, C.; ROMERO, J.; CARACOSTANTÓGOLO, J.; SAUMELL, C.; MEJÍA, M.; COSTA, J.; STEFFAN, P. Resistencia antihelmíntica en bovinos: causas, diagnóstico y profilaxis. Veterinaria Argentina, Buenos Aires, v. 18, n. 171, p. 21-33, Abr. 2003.

GORDON, H. MC. L.; WHITLOCK, H. V. A new technique for counting nematode eggs in sheep faeces. Journal of the Council for Scientific and Industrial Research. Melbourne, v. 12, p. 50-62, Fev. 1939.

HOSKIN, B. C.; KAMINSKY, R.; SAGER, H.; ROLFE, P.F.; SEEWALD, W. A pooled analysis of the efficacy of monepantel, an amino-acetonitrile derivative against gastrointestinal nematodes of sheep. Parasitology Research, Berlin, v. 106, p. 529-532. Jan. 2010. https://doi.org/10.1007/s00436-009-1636-1

KAMINSKY, R.; DUCRAY, P.; JUNG, M.; CLOVER, R.; RUFENER, L.; BOUVIER, J.; WEBWE, S. S.; WENGER, A.; WIELAND-BERGHAUSEN, S.; GOEBEL, T.; GAUVRY,N.; PAUTRAT, F.; SKRIPSKY, T.; FROELICH, O.; KOMOIN-OKA, C.; WESTLUND, B.; SLUDER, A.; MASER, P. . A new class of anthelmintics effective against drug-resistant nematodes. Nature, Londres, v. 452, p. 176-180. Mar. 2008a. https://doi.org/10.1038/nature06722

KAMINSKY, R.; GAUVRY, N.; SCHORDERET WEBER, S.; SKRIPSKY, T.; BOUVIER, J.; WENGER, A.; SCHROEDER, F.; DESAULES, Y.; HOTZ, R.; GOEBEL, T.; HOSKING, B. C.; PAUTRAT, F.; WIELANDBERGHAUSEN, S.; DUCRAY, P. Identification of the amino-acetonitrile derivative monepantel (AAD 1566) as a new anthelmintic drug development candidate. Parasitology Research, Berlin, v. 103, n. 4, p. 931-939. Jul. 2008b. https://doi.org/10.1007/s00436-008-1080-7

KAMINSKY, R.; MOSIMANN, D.; SAGER, H.; STEIN, P.; HOSKING, B. Determination of the effective dose rate for monepantel (AAD 1566) against adult gastro-intestinal nematodes in sheep. International Journal for Parasitology, Melbourne, v. 39, n. 4, p. 443-446. Mar. 2009.

https://doi.org/10.1016/j.ijpara.2008.09.009

MEDEROS, A. E.; RAMOS, Z.; BANCHERO, G. E. First report of monepantel Haemonchus contortus resistance on sheep farms in Uruguay. Parasites \& Vectors, Praga, v. 7, n. 598, p. 1-4. Dez. 2014. 
MELO, A. C. F. L.; REIS, I. F.; BEVILAQUA, C. M. L.; VIEIRA, L. S.; ECHEVARRIA, F. A. M.; MELO, L. M. Nematódeos resistentes a anti-helmíntico em rebanhos de ovinos e caprinos do estado do Ceará, Brasil. Ciência Rural, Santa Maria, v. 33, n. 2, p. 339-344. Abr. 2003. https://doi.org/10.1590/S010384782003000200024

PARK, A. W.; HAVEN, J.; KAPLAN, R.; GANDON, S. Refugia and the evolutionary epidemiology of drug resistance. Biology Letters, London, v. 11, n. 11, rsbl.2015.0783. Nov. 2015.

ROBERTS, F. H. S.; O'SULLIVAN, P. J. Methods for egg counts and larval cultures for strongyles infecting the gastro-intestinal tract of cattle. Australian Journal of Agriculture Research, Melbourne, v. 1, n. 1, p. 99102. 1950. https://doi.org/10.1071/AR9500099

ROSALINSKI-MORAES, F.; MORETTO, L. H.; BRESOLIN, W. S.; GABRIELLI, I.; KAFER, L.; ZANCHET, I. K.; SONAGLIO, F.; THOMAZ-SOCCOL, V. Resistência anti-helmíntica em rebanhos ovinos da região da associação dos municípios do Alto Irani (AMAI), Oeste de Santa Catarina. Ciência Animal Brasileira, Goiânia, v. 8, n. 3, p. 559-565. Set. 2007.

SCOTT, I.; POMROY, W. E.; KENYON, P. R.; SMITH, G.; ADLINGTON, B.; MOSS, A. Lack of efficacy of monepantel against Teladorsagia circumcincta and Trichostrongylus colubriformis. Veterinary Parasitology, Genebra, v. 198, n. 1-2, p. 166-171. Nov. 2013. https://doi.org/10.1016/j.vetpar.2013.07.037

SCZESNY-MORAES, E. A.; BIANCHIN, I.; SILVA, K. F.; CATTO, J. B.; HONER, M. R.; PAIVA, F. Resistência anti-helmíntica de nematóides gastrintestinais em ovinos, Mato Grosso do Sul. Pesquisa Veterinária Brasileira, Rio de Janeiro, v. 30, n. 3, p. 229-236. Mar. 2010.

SOUZA, A. P.; RAMOS, C. I.; BELATTO, V.; SARTOR, A. A.; SCHELBAUER, C. A. Resistência de helmintos gastrintestinais de bovinos a anti-helmínticos no Planalto Catarinense. Ciência Rural, Santa Maria, v. 38, n. 5, p. 1363-1367. Ago. 2008.

SPRENGER, L. K.; AMARAL, C. H.; FILHO, R. V. L.; AGUIAR, T. N.; MOLENTO, M. B. Eficácia do fosfato de Levamisol em nematódeos gastrintestinais de caprinos e ovinos. Archives of Veterinary Science, Curitiba, v. 18, n. 1, p. 29-39. Jan. 2013.

TORRES-ACOSTA, J. F. J.; MOLENTO, M.; MENDOZA DE GIVES, P. Research and implementation of novel approaches for the control of nematode parasites in Latin America and the Caribbean: Is there sufficient incentive for a greater extension effort? Veterinary Parasitology, Genebra, v. 186, n. 1-2, p. 132-142. Mai. 2012.

VAN DEN BROM, R.; MOLL, L.; KAPPERT, C.; VELLEMA, P. Haemonchus contortus resistance to monepantel in sheep. Veterinary Parasitology, Genebra,, v. 209, n. 3-4, p. 278-280. Abr. 2015. https://doi.org/10.1016/j.vetpar.2015.02.026

VAN WYK, J. A.; CABARET, J.; MICHAEL, L. M. Morphological identification of nematode larvae of small ruminants and cattle simplified. Veterinary Parasitology, Genebra, v. 119, n. 4, p. 277-306. Fev. 2004. https://doi.org/10.1016/j.vetpar.2003.11.012

VERÍSSIMO, C. J.; NICIURA, S. C. M.; ALBERTI, A. L. L.; RODRIGUES, C. F. C.; BARBOSA, C. M. P.; CHIEBAO, D. P.; CARDOSO, D.; SILVA, G. S.; PEREIRA, J. R.; MARGATHO, L. F. F.; COSTA, L. R. D.; NARDON, R. F.; UENO, T. E. H.; CURCI, V. C. L. M.; MOLENTO, M. B. Multidrug and multispecies resistance in sheep flocks from Sao Paulo state, Brazil. Veterinary Parasitology, Genebra, v. 187, n. 1-2, p. 209-216. Jun. 2012. https://doi.org/10.1016/j.vetpar.2012.01.013

WURSHORN, L.; MARTIN, P. Reso: faecal egg count reduction test (FECRT) Analysis Program 2.01. Parkville: CSIRO Animal Health Research Laboratory, 1990. 